\title{
Finite volume coastal ocean model for water-level fluctuation due to climate change in Aguelmam Sidi Ali Lake (Middle Atlas, Morocco)
}

\author{
Soufiane Haddout ${ }^{1, *}$, Abdelkrim Jamali ${ }^{2}$, Mbarek Rhazi $^{2}$ and Mohamed Aghfir ${ }^{2}$ \\ ${ }^{1}$ Department of Physics, Faculty of Sciences, Ibn Tofail University, B.P242, 14000 Kenitra, Morocco \\ 2 Department of Physics, Ecole Normale Superieure, B.P2400, 40000 Marrakech, Morocco
}

Received: 13 July 2017; Accepted: 14 December 2017

\begin{abstract}
Climate changes are the main motivation for alteration of ecosystems; in fact the effects of these changes on biodiversity and ecosystems are considered as the most challenging cases in present century. Therefore, since the lakes are the most important services and functions of ecosystems, the effect of climate change on water level fluctuations of Aguelmam Sidi Ali Lake (Morocco) was analyzed as a natural ecosystem in this essay. The regular observations from the lake have found that a very sensitive withdrawal of their water level during the dry years. Therefore, a hydrodynamic model has been used to simulate the condition of Aguelmam Sidi Ali Lake, with observed field data (model has been set up to run annually for a total 35 year data, i.e., precipitation, evaporation, runoff discharges and water-level which are available for the last 35 years) being used for model calibration and validation. Additionally, the model validation process showed that the model results fit the observed data fairly well $\left(R^{2}=0.70-0.74\right.$, root mean square error $[R M S E]=1.63-1.71 \mathrm{~m})$. On the other hand, different hydrological conditions regarding lake input and output data were tested and water depth was calculated using bathymetry to predict water-level fluctuations in the future. The results predict that the water-level will decrease continuously (In 2044, the water level will reach to $6.20 \mathrm{~m}$ ). The water level decrease due to the climate change in both scenarios (dry and very dry) is dramatic and a profound adverse impact on the environmental balance is predicted in the region. Additionally, the lake will be dried up in about 20 years if very dry conditions continue in the region. This reveals the importance of this type of approach for obtaining a first-order estimate of water-level variations in Sidi Ali Lake, affected by climate change.
\end{abstract}

Keywords: Climate change / ecosystem / Aguelmam Sidi Ali Lake / water-Level fluctuation / modeling / management

\section{Introduction}

The climate change has been a major concern for decision makers in recent years. This change can lead to numerous problems in the ecosystem and the climate of the area. The possible outcome should be anticipated by experts in different fields and the predicted losses should be calculated to clarify the impact of its destruction. Additionally, climate change is expected to cause significant changes to the hydrology of lakes, reservoirs and other wetlands. In particular, there will be an increase in the level of disturbance produced by water-level fluctuations (WLF). Increased temperatures could have implications for Great Lakes water levels (International Joint Commission, 2012). Actually, in recent years fluctuations of the basin water levels are influenced by changes in precipitation, evaporation, and evapotranspiration (Bartolai

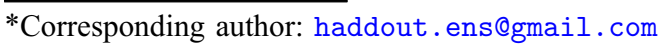

et al., 2015) and these water bodies have been significantly affected by global warming and climate change (Finlayson et al., 2013), and lake levels are likely to continue to fluctuate. On the other hand, due to increasing water consumption in dry regions, lakes and other aquatic ecosystems are under increasing pressure (Coops et al., 2003; Haghighi et al., 2014; Yuan et al., 2015). Therefore, with respect to the destruction aquatic ecosystems and knowing this subject that climate change has a significant impact on the natural hydrological cycle and amplifies water scarcity in (semi)-arid regions (Fernandes et al., 2011; Haddeland et al., 2014; Santos et al., 2014), understanding the effects of temperature increases on patterns of biodiversity is of fundamental importance to quantifying the ecological and economic risks of climate change (Brooks and Newbold, 2014) that the responses in lake water levels can be used as an indicator to assess the overall regional hydrological impacts of climate change, land use change and river regime modifications (Coops et al., 2003; Pengra, 2012; Jin and Feng, 2013; 
Moftakhari et al., 2013; Hassan and Jin, 2014; Muvundja et al., 2014; Haghighi and Klove, 2015; Yuan et al., 2015; Haghighi et al., 2016).

Climate change has been a topic of interest for many researchers: the effects of climate change to increase level of Victoria Lake in east of Africa were analyzed by Mistry and Conway (2003). The results showed that there were direct relation and correlation between fluctuation of lake's level and precipitation on the lake surface. Findings of Guo et al. (2006) showed that because of severe impact of region's weather on water surface of Poyang Lake and water sources in China, it is expected that the hydrological processes and water evacuation to the lake will be changed in the future. Mendoza et al. (2006) in an effort analyzed the reasons of Cuitzeo lake's changes in Mexico; they used statistical models to link fluctuations of water level to rainfall and temperature; for this purpose the time series was used. Ryner et al. (2007) in the postglacial warm period studied the restoration of local response of lake to regional climate change and hydrological instability. Motiee and McBean (2009) also found that the climate change causes to reduce $50 \mathrm{~cm}$ water level of the Superior Lake located on North America that is the lowest amount in the past 81 years. They also found that in a short period of time, water level of lake has been decreased one centimeter in every year and given to obtain results they found that these changes can indicate signs of climate change phenomenon in the studied area. Zilefac (2010) showed that by reducing rainfall and increasing temperature the average depth of Chad Lake has fallen from about $7 \mathrm{~m}$ to $1.5 \mathrm{~m}$. Njaya et al. (2011) stated that average depth of Chilwa Lake has been decreased from 0 to $12 \mathrm{~m}$ between 1960 and 2000, Huang et al. (2011) considered the temperature and precipitation as the most important factors affecting on fluctuations of Cottonwood Lake in United State. Mekonnen et al. (2012) pointed out that depth of Naivasha lake has been decreased $4 \mathrm{~m}$ between 1965 and 2001, and Zawiska et al., (2015) by using results of several indexes analysis (palynology, sedimentology, chemical composition and paleontology) clearly showed that weather has been the main motivation of change in aquatic and terrestrial ecosystems as well as geomorphologic processes of eastern Poland basin.

We can cited also that the Fuzzy approach (Altunkaynak and Sen, 2007), artificial neural network (Vaziri, 1997), probable water level curves (Woodbury and Padmanabhan, 1989) and Multi-temporal Landsat data TM-5 (Thematic Mapper) and OLI-8 (Operational Land Imager) approach (Menjour et al., 2016), are some methods used to study the water level variations.

Recently, Menjour et al. (2016) used Multi-temporal Landsat data to study the water level of Sidi Ali Lake from 1985-2015 with a focus on climate change. Since an approximate water level/volume formula (Sayad et al., 2011) and mapped surface (Menjour et al., 2016) was applied and the severe drought data were not used, it is necessary to simulate the future lake water level by applying a more flexible method using real conditions and taking into account its bathymetry.

To apply bathymetry and the drought conditions, hydrodynamic models (2D or 3D) can be used. 3D models can present more reliable and rational hydrodynamic simulations (Zeinoddini et al., 2009). Here, a 3D model (i.e., finite volume coastal ocean model (FVCOM)) capable of accurately solving the scalar conservation equations along with topological flexibility provided by unstructured meshes was used (Chen et al., 2003).

Previously, such models were normally used for a specific condition (extreme condition: tsunami simulation or calibration cases: tidal waves (Zhaoqing and Tarang, 2008) and limited duration (for several hours or days), but not for water level predictions over a period of several years.

The focus of this study is Aguelmam (Lake) Sidi Ali (Fig. 1). As the largest and deepest perennial lake in the Middle Atlas, the site offers great potential for addressing key regional environmental and climatic questions.

In addition, due to 15 years of progressive dry climate, the lake water level has been decreased about $6.9 \mathrm{~m}$ (Sayad et al., 2011) and also there is a great concern about its impending drought in the future.

In this paper, a scientific model of natural and engineered environments has been applied, that combines a hydrodynamic model with different hydrological periods to predict the coming year's water level fluctuations in the Sidi Ali Lake for the first time in this region (Middle Atlas); to find its environmental condition and probability of its drought in near future; and in selection of the scenarios to take the most fitted one to evaluate the future changes in the environment.

\section{Materials and methods}

\subsection{Study area}

The Middle Atlas range is an intercontinental fold-thrust belt that extends for around $250 \mathrm{~km}$ in northern Morocco along a primarily SW-NE alignment (Arboleya et al., 2004) and reaches elevations in excess of 3300 m.a.s.l. in the eastern sector. The dominant geology of the Middle Atlas is Mesozoic limestones giving rise to significant karstification of the landscapes. A legacy of Plio-Pleistocene volcanism is also highly evident in regional landforms (De Waele and Melis, 2009). Located on one of the main regional SW-NE trending lineaments, Lake Sidi Ali $\left(33^{\circ} 03^{\prime} \mathrm{N}, 05^{\circ} 00^{\prime} \mathrm{W}\right)$ is one of the largest (surface area of up to $2.8 \mathrm{~km}^{2}$ ), highest ( $2080 \mathrm{~m}$.a.s.l.) and deepest (up to $40 \mathrm{~m}$ water depth) lakes in the karstic uplands of the western Middle Atlas Mountains in Morocco. The lake is located within a small closed catchment $\left(14 \mathrm{~km}^{2}\right)$ that reaches up to around 2400 m.a.s.l. in elevation. The lake lies in a structural depression at the contact between Middle Jurassic limestones and Lower Jurassic dolomites. In September 2012, the lake displayed a maximum water depth of $38 \mathrm{~m}$ and anaerobic conditions at the hypolimnion (Zielhofer et al., 2017). A shallow sub-basin to the SW is partly separated from the main basin by early Quaternary basalt flows. The two basins are linked when lake levels are at their highest (Lamb et al., 1999); they are currently separated due to lake lowering trends in recent decades (Menjour et al., 2016). There are no significant surface inlet or outlet streams, and lake levels are sensitive to annual precipitation variability (Sayad et al., 2011).

Located at the southern margins of the Middle Atlas, Lake Sidi Ali is situated near the transition between the Atlantic, Mediterranean and Saharan climatic zones (Knippertz et al., 2003; Born et al., 2010). The regional climate is Mediterranean with summer drought influenced by the sub-tropical high 


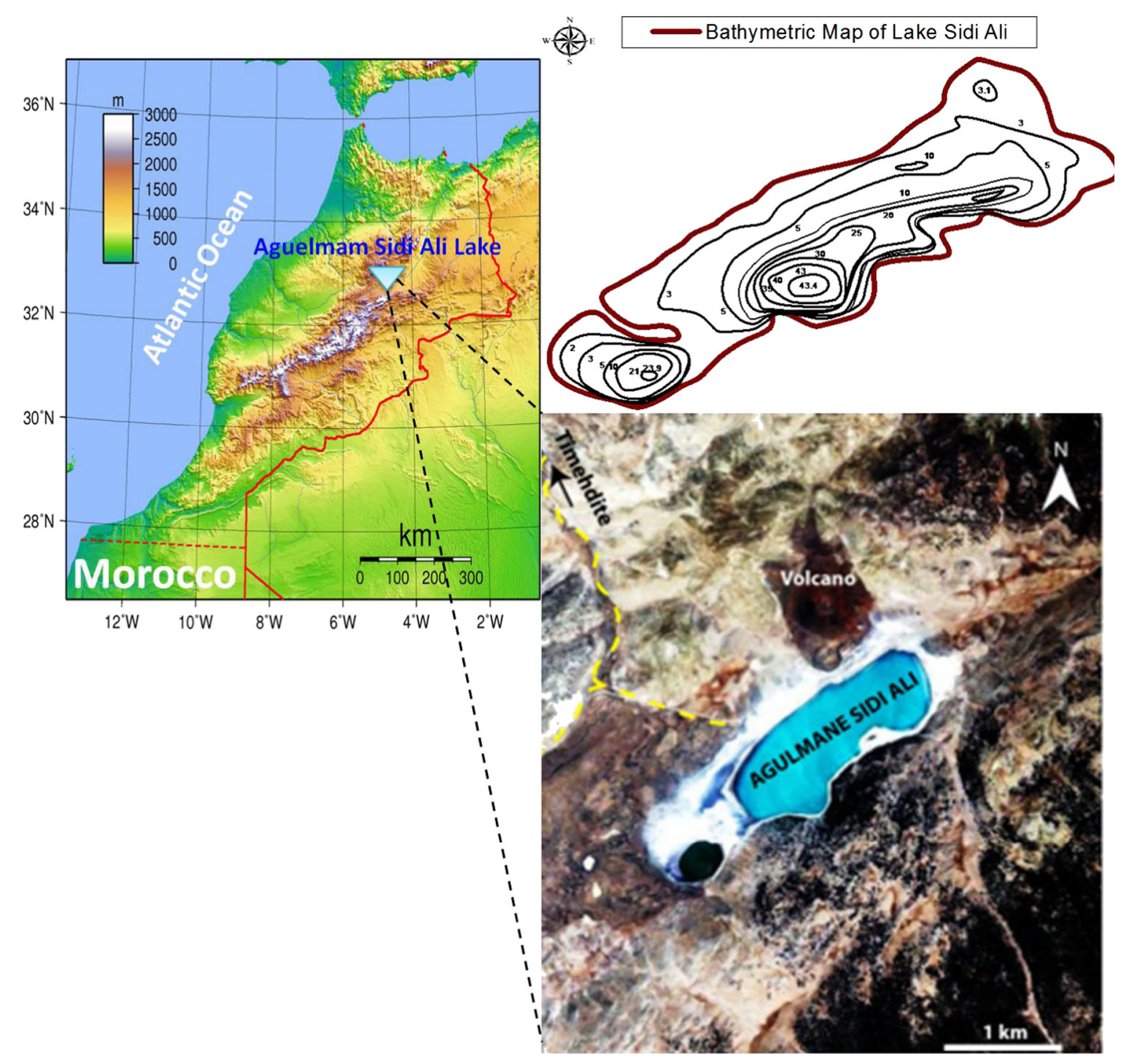

Fig. 1. Geographical locations of the Aguelmam Sidi Ali Lake (Morocco).

pressure belt and humid winters impacted by the Atlantic westerly circulation. Across the Middle Atlas, a strong NW to SE gradient of increasing aridity is evident, with high rainfall due to orographic effects at the NW margins of the Middle Atlas near Ifrane, and drying associated with subsequent Foehn effects as northwesterly air masses cross the SW-NE ridges of the Middle Atlas (Rhanem, 2009). The mean annual precipitation of $430 \mathrm{~mm}$ was recorded between 1982 and 2009, with maxima in spring (April-May) and late autumn/ winter (November-December), as well as torrential summer storms associated with convection along the Atlas-Sahara margins. The lake stratifies during the summer, and typical stratification periods last from June to September. Summer (June-August) mean surface water temperature is $19.8^{\circ} \mathrm{C}$, and hypolimnetic water temperatures vary between 5 and $10^{\circ} \mathrm{C}$; however, some years reach temperatures of only $4.5-6{ }^{\circ} \mathrm{C}$ in the hypolimnion due to shortened spring mixing durations.

On the other hand, the decreasing in temperature at the end of each period was accompanied by an increase in precipitation, a decrease in evapotranspiration, and a rise in the water level of Sidi Ali Lake (see Fig. 2). Additionally, the general temperature within our study area has increased. We explained this phenomenon as part of the climate dynamics of this region. The relationships between the lake level variations and the average temperature within the Sidi Ali Lake are shown in Figure $2 \mathrm{~b}$. The changes in the average annual precipitation (Fig. 2a), evapotranspiration rate (Fig. 2c), and temperature (Fig. 2b) were closely correlated with the water level changes of Sidi Ali Lake.

Menjour et al. (2016) mapped the surface area changes for Sidi Ali Lake during 1975, 1985, 1995, 2007 and 2015 concluding that the water area is reduced in the dry period to 155 ha in 2007; with a stored volume less than $18 \mathrm{Mm}^{3}$. In wet period, this area had reached more than 300 ha in 1975 with volume of water stored of $35 \mathrm{Mm}^{3}$.

\subsection{Model description}

FVCOM is an unstructured grid, finite volume, 3-D primitive equation coastal ocean model developed by 
(a)

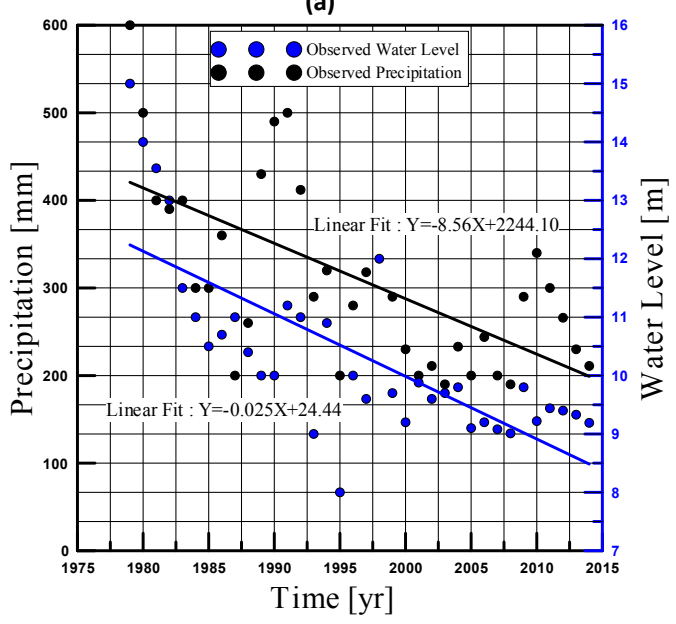

(b)

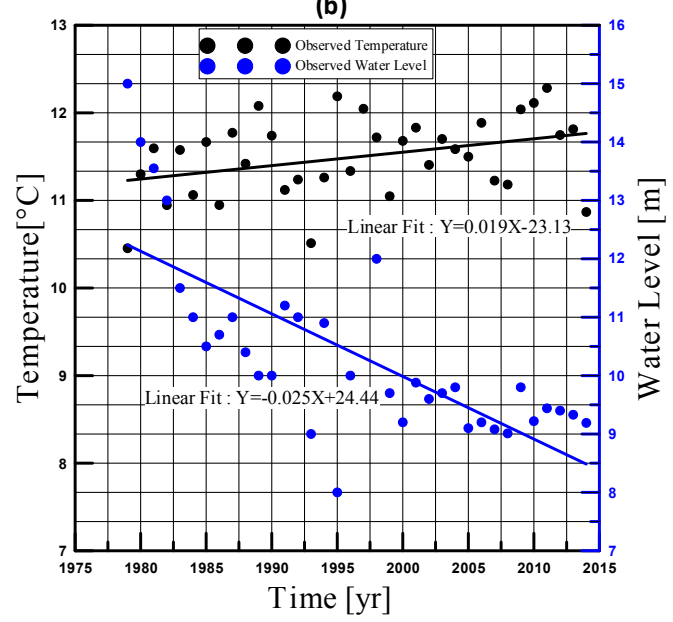

(c)

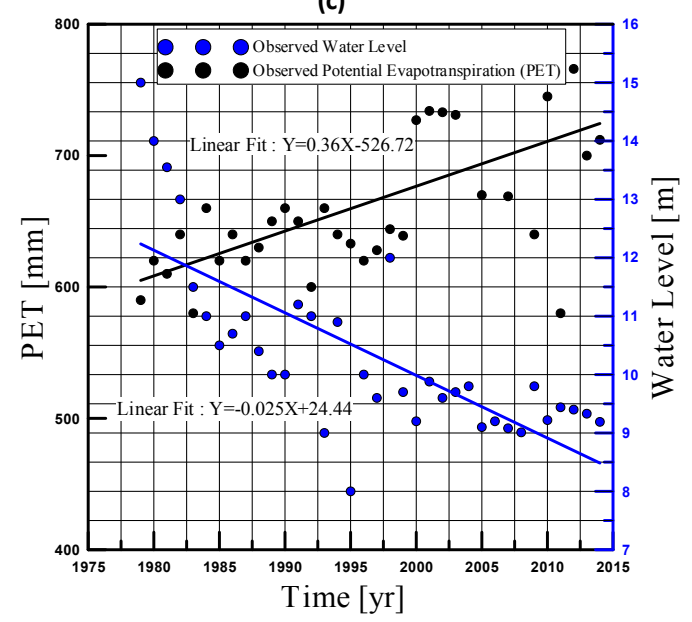

Fig. 2. (a) Mean yearly precipitation and water level (1979-2014); (b) Mean yearly temperature and water level variations (1979-2014); (c) Mean yearly evapotranspiration and water level (1979-2014).

Chen et al. (2003) and upgraded by joint efforts of scientists at University of Massachusetts-Dartmouth and Woods Hole Oceanographic Institution (Chen et al., 2006a, b; Chen et al., 2007; Huang et al., 2008). FVCOM is discretized with triangular grids in the horizontal and generalized terrain following coordinate in the vertical. The model utilizes the modified Mellor and Yamada (1982) level 2.5 (MY-2.5) and Smagorinsky turbulent closure schemes as default setups for vertical and horizontal mixing, respectively, with an option for various turbulent parameterizations using the Generalized Ocean Turbulence Model (GOTM) (Burchard, 2002). FVCOM includes both hydrostatic and non-hydrostatic dynamics (Lai et al., 2010a, b), and can be solved either by mode- split scheme or semi-implicit scheme. The current version of FVCOM used in this study includes wetting/drying treatment, 3D sediment module, ice module, etc. In a generalized terrain-following coordinate system, the governing equations of momentum, continuity, temperature, salinity, and density with the inclusion of three-dimensional radiation stress (Mellor, 2003, 2005, 2008) (see Eqs. (1)-(6) in Chen et al., 2003). On the other hand, the equations of conservation of mass, momentum and turbulent closure in $r$ coordinate system are used in the hydrodynamic model based on sigma transformation to describe the flow and water-level variations (according to Blumberg and Mellor, 1978, 1987). FVCOM is solved numerically by a second-order accurate discrete flux calculation in the integral form of the governing equations over an unstructured triangular grid (Abbaspour et al., 2012). This approach combines the best features of finite-element methods (grid flexibility) and finite difference methods (numerical efficiency and code simplicity) and provides a much better numerical representation of momentum, mass, salt, and heat conservation. FVCOM includes a mass conservative wet/dry point treatment technique to simulate the flooding/drying process over the coasal-estuarine-tidal and creek-intertidal marsh complex (see http://fvcom.smast.umassd.edu/fvcom/). A second-order accurate four-stage Runge-Kutta time-stepping scheme is used for external mode time integration while the first-order Euler forward scheme is used for internal mode time integration (Chen et al., 2003). A second-order accurate upwind scheme, which is based on piecewise linear reconstruction of dynamic variables is used for flux calculation of momentum and tracer quantities (Kobayashi et al., 1999; Hubbard, 1999). Comparisons (Chen et al., 2007; 
Huang et al., 2008) between (FVCOM), (POM) and (ECOMsi) solutions for a variety of test cases for lake (wind induced long-surface gravity waves in an idealized circular lake and for freshwater discharge experiments on idealized shelves in a circular lake) demonstrate that the finite-volume method used in FVCOM provides a more accurate simulation than the two finite difference models in cases with complex coastal geometry and steep bottom slopes. In particular, the finite volume methods ensure volume, mass and tracer conservation in the individual control volumes and the unstructured triangular grid can be closely fit to an irregular coastline and model domains, resulting in highly accurate numerical solutions in even quite complex model geometries. With second-order accuracy, FVCOM combines the advantage of finite element methods for geometric flexibility and finite difference methods for simple discrete code structure and computational efficiency (Chen et al., 2007). The ability of FVCOM to accurately solve scalar conservation equations in addition to the topological flexibility provided by unstructured meshes and the simplicity of the coding structure makes FVCOM ideally suited for interdisciplinary application for coastal oceans, estuaries, and lakes.

\subsection{Model performance verification}

The statistical indicators used for evaluating the performance of the model are: root mean squared error (RMSE); mean absolute error (ABSERR); the Nash Sutcliffe modelling efficiency index $(E F)$; the goodness-of-fit $\left(R^{2}\right)$ and the \% of deviation from observed streamflow (PBIAS). The statistical parameters were defined as follows (Moriasi et al., 2007; Stehr et al., 2008; Conversa et al., 2015; Haddout et al., 2017a, 2017b; Haddout et al., 2016):

$$
\begin{gathered}
R M S E=\sqrt{\left[\frac{\sum_{i=1}^{n}\left(W L_{\text {meas }, i}-W L_{\text {pred }, i}\right)^{2}}{N}\right]}, \\
A B S E R R=\left[\frac{\sum_{i=1}^{n}\left(W L_{\text {meas }, i}-W L_{\text {pred }, i}\right)}{N}\right], \\
E F=1-\left[\frac{\sum_{i=1}^{n}\left(W L_{\text {meas }, i}-W L_{\text {pred }, i}\right)^{2}}{\sum_{i=1}^{n}\left(W L_{\text {meas }, i}-W L_{\text {meas }}\right)^{2}}\right], \\
{\left[\frac{R^{2}=}{\left(\sum_{i=1}^{n}\left(W L_{\text {meas }, i}-W L_{\text {meas }}\right)^{2}\right)^{1 / 2}\left(\sum_{i=1}^{n}\left(W L_{\text {pred }, i}-W L_{\text {pred }}\right)^{2}\right)^{1 / 2}}\right]^{2}} \\
P B I A S=\left[\frac{\sum_{i=1}^{n}\left(W L_{\text {meas }, i}-W L_{\text {pred }, i}\right)}{\sum_{i=1}^{n}\left(W L_{\text {meas }, i}\right)} 100\right],
\end{gathered}
$$

where $W L_{\text {meassi }}$ is the observed value and $W L_{\text {predsi }}$ the

\begin{tabular}{|c|c|}
\hline \multirow[t]{2}{*}{ Scenarios } & Historical data \\
\hline & Wet (1979-1984) Dry (1986-1993) Very dry (1993-2010 \\
\hline 1 & - \\
\hline 2 & - \\
\hline 3 & • \\
\hline
\end{tabular}
computed value of water level. $W L_{\text {meas }}$ is the mean observed water level data and $W L_{\text {pred }}$ is the mean computed water level.
Table 1. Scenarios for different hydrological period simulation continued in near future (for 33 years).

The closer the values of RMSE and ABSERR to zero, and the $R^{2}$ to unity, the better the model performance is evaluated (El-Nasr et al., 2005). For Percent bias (PBIAS) measures the average tendency $P B I A S$, expressed as a percentage, of the simulated data to be larger or smaller than their observed counterparts (Gupta et al., 1999). The optimal value of PBIAS is 0 , with low-magnitude values indicating accurate model simulation (Moriasi et al., 2007). Positive values indicate model underestimation bias and negative values indicate model overestimation bias (Gupta et al., 1999). The NashSutcliffe efficiency $(E F)$ (Nash and Sutcliffe, 1970) is a normalized statistic that determines the relative magnitude of the residual variance (noise) compared to the measured data variance (information). $E F$ ranges between $-\infty$ and 1 (1 inclusive), with $E F=1$, the closer the model $E F$ efficiency is to 1 , the more accurate is the model. Values between 0 and 1 are generally viewed as acceptable levels of performance, whereas values $\leq 0$ indicate unacceptable performance (Moriasi et al., 2007).

\subsection{Model inputs}

Sidi Ali Lake is a closed-basin lake with a hydraulic regime highly dependent on annual climate conditions. Hence, the applied model inputs are annual meteorological and hydrological data including precipitation, evaporation, and runoff discharge to the lake. The stations, used in this study, are administrated by Hydraulic Basin of Sebou Agency (ABHS) in Sidi Ali Lake with more than 30 years of daily recording. It should be noted that all of these parameters are retrieved from the approved report by Hydraulic Basin of Sebou Agency (ABHS, 2007, 2009) for water balance studies in the water basin of the lake (during 1979-2010). The data reliability of these studies was already confirmed by Sayad et al., (2011) which was prepared for conservation of wetlands Middle Atlas in Moroccan.

In June 1975, after the measures carried out by the Public Laboratory of tests and studies (LPEE-Casablanca), the lake was full and ranged in depth to more than $\sim 46 \mathrm{~m}$, the water area represented 337 ha for the volume stored 35 million $\mathrm{m}^{3}$ (ABHS, Unpublished document).

\subsection{Scenarios}

As seen in Table 1, the lake has encountered alternately wet, dry and very dry periods. After the wet period of 19791984 and by the beginning of dry period (1986-1993), the lake water level has decreased continuously. The reduction in water 


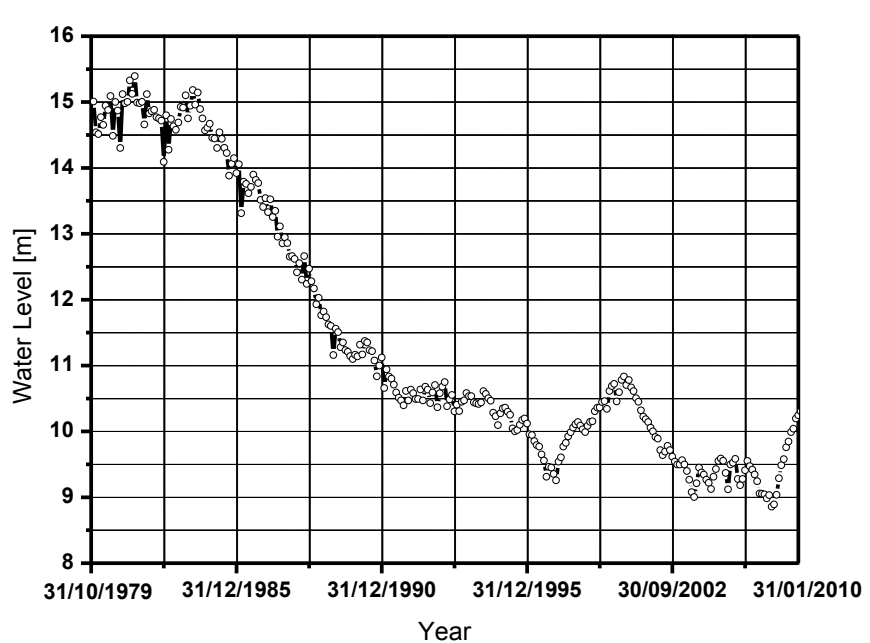

Fig. 3. Variation of the water level in Sidi Ali Lake from 1979 to 2010 .

level (since 1984) due to climate change is $68 \%$ relative to wet periods from 1979 to1984. Since it is not clear how much the drought can affect the lake level in near future, the present condition has been used to set up a model for different scenarios (i.e., wet, dry and very dry periods) as illustrated in Table 1. The scenarios can be applied for 33 years (20112044).

The following scenarios (Tab. 1) are used to find water level fluctuations (during 2011-2044) due to climate change trend, then the scenario which best fit the lake fluctuation during (2012-2016) is selected to set up the model for other conditions:

- Model run for continuous wet period.

- Model run for continuous dry period.

- Model run for continuous very dry period.

\section{Results and discussion}

\subsection{Calibration and validation}

The variation in the lake level during the period from 1979 to 2010 is shown in Figure 3. There was a significantly decreasing trend in the lake level during the period 1979-1984. Generally, the lake level was $15.63 \mathrm{~m}$ in 1979-1984 and gradually fell to $10.5 \mathrm{~m}$ in 1986-1996, resulting in a total decline of $5.13 \mathrm{~m}$, with an average decreasing rate of $0.20 \mathrm{~m}$ year $^{-1}$ over 17 years. However, there appeared to be a significant increasing trend during the period of 1996-2000; the lake level had risen by $1.30 \mathrm{~m}$; and gradually fell to $9.17 \mathrm{~m}$ in 2002-2008.

The model predictions are calibrated by comparing the water level observed with water level computed. The periods chosen for the calibration was from 1979 to 1990 (observational data for 11 years) and the data during 1991-2010 (19 years) have been used to validate the model results. The simulation performed satisfactory in capturing water level variability in the Sidi Ali Lake. Comparison between observed and computed water level (Tab. 2; Fig. 4a, b) shows $8 \%$ and $10 \%$ errors, respectively.
On the other hand, a constant coefficient (pan coefficient) of the reference evapotranspiration is used as input for the model. The $K_{p}$ values depend on fetch, relative humidity and wind speed. This coefficient was ranging from 0.35 to 0.85 for different conditions (Allen et al., 1998). For the case in which the pan is surrounded by short green cropped area, the pan coefficient is estimated initially based on Class-A pan equation (Allen et al., 1998):

$$
\begin{aligned}
K_{p} & =0.108-0.02861 U+0.0422 \ln (F) \\
& +0.1434 \ln (R H)-0.000631[\ln (F)]^{2}[\ln (R H)],
\end{aligned}
$$

where $U$ is the wind speed at $2 \mathrm{~m}$ above the ground; $\mathrm{F}$ is the distance field/area cultivated or uncultivated land around the basin to a barrier against the wind $(\mathrm{m})$, it may take from 1 to $1000 \mathrm{~m}$; and $R H$ is the relative humidity (\%). A value of $K_{p}=0.39$ is used in this work. This constant coefficient is almost equal to the slope of regression line obtained in Figure 2c (i.e., evapotranspiration).

\subsection{Sidi Ali Lake's fate due to climate change}

The results (Fig. 5) reveal that only in scenarios (1), the lake level is environmentally desirable (2011-2044). In other scenarios, there is a continuous decline in water level with undesirable environmental conditions. The conditions become progressively worse in scenarios (2) and (3); in 2044, the water level will reach to $6.20 \mathrm{~m}$. The water level decrease due to the climate change in both scenarios is dramatic and a profound adverse impact on the environmental balance is predicted in the region.

After these simulations, the recorded data were compared (Fig. 6) with the output from different scenarios (2012-2016) to select the scenarios that best fit the current condition. These scenarios are used to predict the future of the lake due to drought in this section.

As it can be seen, the current trend of water level decrease is to some extent similar to the continuation of dry and very dry periods in future (scenarios 2 and 3 ).

We can summarizing that the WLF in lakes are dominant forces controlling the functioning of lacustrine ecosystems. The main objective of this simulation method is to accelerate and facilitate of systems' behavior learning in the current and future situation in this region. Additionally, it is an advantage for decision makers to change the input parameters to decide how to regulate the lake in connection with the climate change (dry or wet period). Another's advantage of the model that is not a time-consuming approach and can be used to show the impact of both dam construction and water usage plans more reliably and faster than other methods such as neural network in the future.

The predictions for two selected scenarios (i.e., dry and very dry) show that in 2044, the water level will fall below the normal condition, which will disturb the lake ecosystem. For example: Biota, in particular those living in vegetated riparian areas, respond differentially to water-level dynamics, either directly or indirectly. Direct effects on the biological communities include physical disturbance by wave activity. Indirect effects include the reworking of substrates (which can enhance or restrict colonization by vegetation, and which in 
Table 2. Statistical indicators of the models performance, during the calibration and validation periods of the Sidi Ali Lake.

\begin{tabular}{|c|c|c|c|c|c|c|c|c|c|c|}
\hline Lake & \multicolumn{6}{|c|}{ Model calibration (1979-1990) } & \multicolumn{4}{|c|}{ Model validation (1991-2010) } \\
\hline Sidi Ali & 1.63 & 1.03 & 0.74 & 0.75 & 1.20 & 1.71 & 1.41 & 0.70 & 0.71 & 1.40 \\
\hline
\end{tabular}
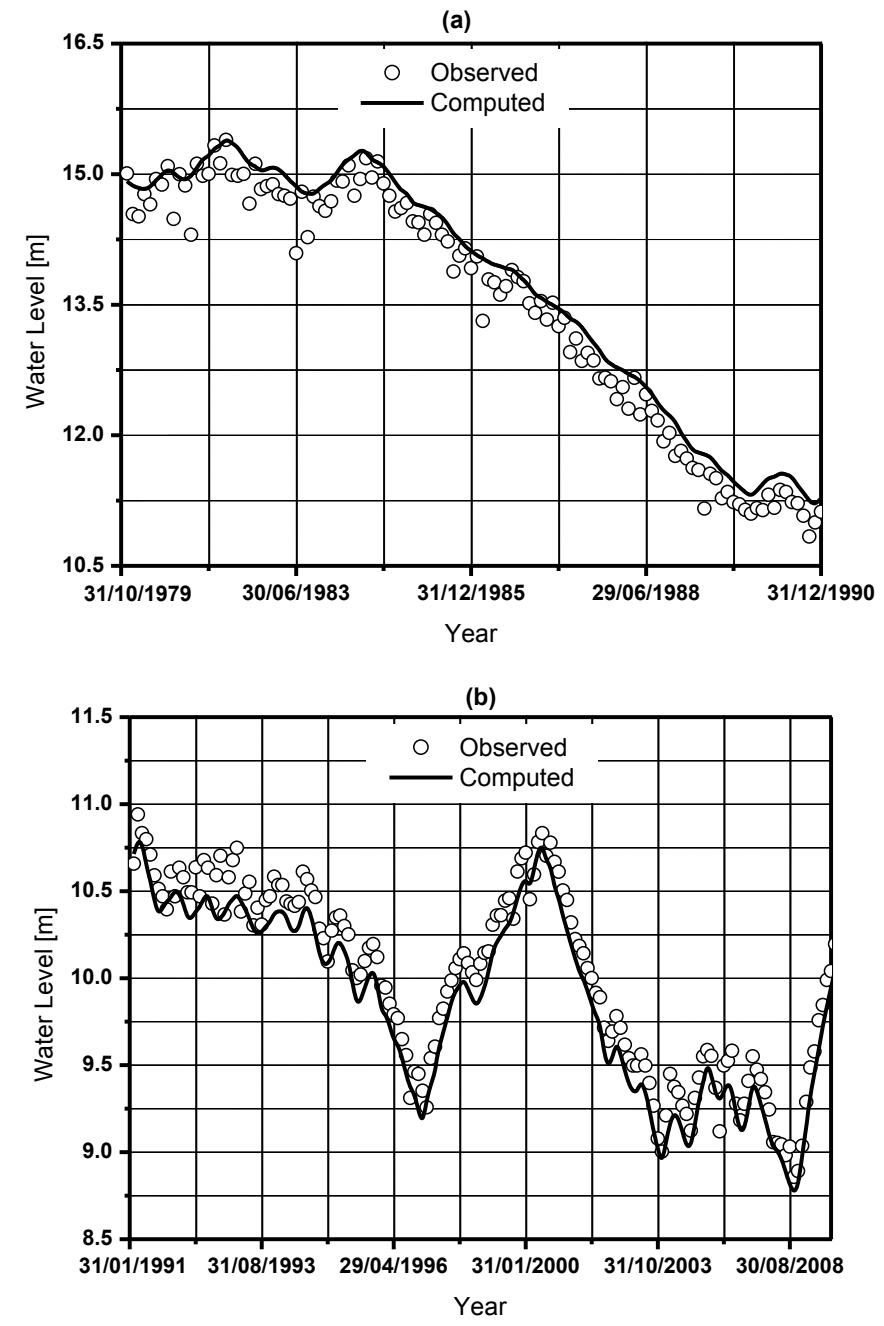

Fig. 4. (a) Comparison between observed and calculated water levels (m) (during 1979-1990) (Calibration) and; (b) during 1991-2010 (Validation).

turn depends on silt accumulation to establish roots), and alteration of habitats suitable for aquatic flora and fauna. Any significant change to the water level of a lake will affect not only the physical processes, but also the biological productivity. Therefore, WLF might have an overriding effect on Lake Ecosystem health and integrity.

\section{Conclusions}

An unstructured grid, finite volume model has been used to simulate the water level of Aguelmam Sidi Ali Lake (Middle Atlas, Morocco) for the first time, with observed

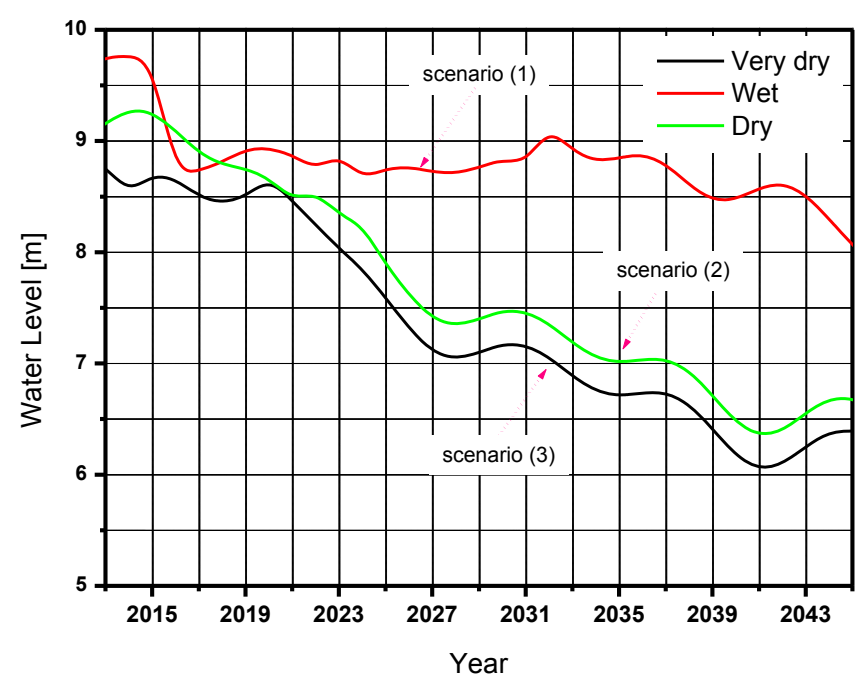

Fig. 5. Comparison of computed water level (m) in different hydrological period condition.

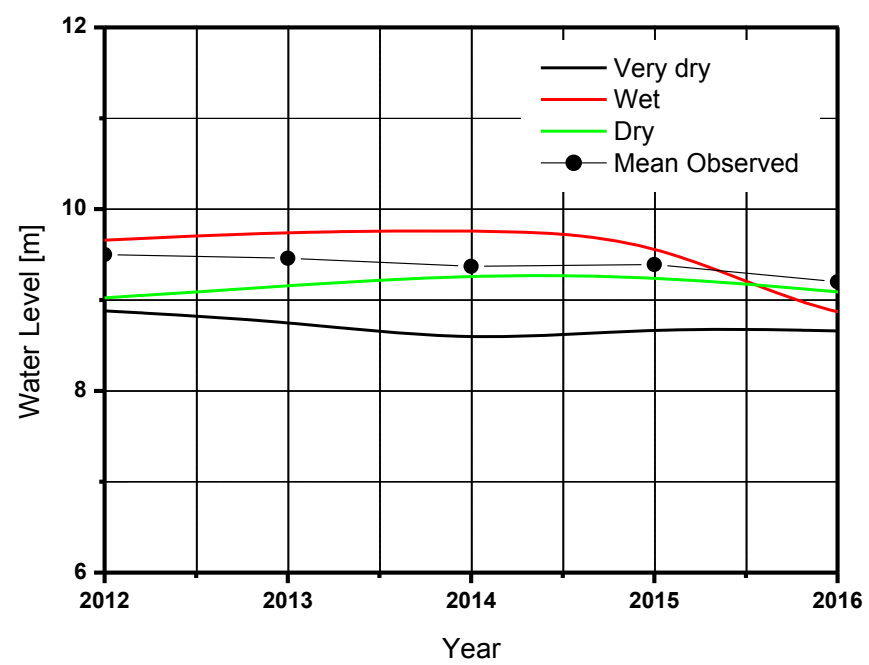

Fig. 6. Comparison between mean value observed and calculated water levels $(\mathrm{m})$ in dry, very dry, and wet period condition (20122016).

field data being used for model calibration and validation. Additionally, the model validation process showed that the model results fit the observed data fairly well. On the other hand, different hydrological conditions regarding lake input and output data were tested and water depth was calculated using bathymetry to predict water level fluctuations in the future. The results predict that the water level will decrease 
continuously. The lake will be dried up in about 20 years if very dry conditions continue in the region. The predictive model can be used to obtain a first-order estimation of water-level variations in Sidi Ali Lake, affected by climate change.

Acknowledgements. The authors gratefully acknowledge anonymous reviewers for their scientific suggestions and constructive comments.

\section{References}

Abbaspour M, Javid AH, Mirbagheri SA, Givi FA, Moghimi P. 2012. Investigation of lake drying attributed to climate change. Int $J$ Environ Sci Technol 9: 257-266.

ABHS. 2007. Situation hydrologique du Bassin de Sebou, année hydrologique 2006/2007. Bulletin de l'Agence Hydraulique du Bassin du Sebou (ABHS), n 20, 19 p.

ABHS. 2009. Situation hydrologique du Bassin de Sebou, année hydrologique 2008/2009. Bulletin de l'Agence Hydraulique du Bassin du Sebou (ABHS), n 21, 24 p.

Allen R, Pereira L, Raes D, Smith M. 1998. Crop evapotranspirationGuidelines for computing crop water requirements. In FAO Irrigation and drainage, paper 56. Rome: FAO, $301 \mathrm{p}$.

Altunkaynak A, Sen Z. 2007. Fuzzy logic model of lake water level fluctuations in Lake Van, Turkey. Theor Appl Climatol 90: 227233.

Arboleya ML, Teixell A, Charroud M, Julivert M. 2004. A structural transect through the High and Middle Atlas of Morocco. J Afr Earth Sci 39: 319-327. DOI:10.1016/j.jafrearsci.2004.07.036.

Bartolai AM, He L, Hurst AE, Mortsch L, Paehlke R, Scavia D. 2015. Climate change as a driver of change in the Great Lakes St. Lawrence river basin. J Gt Lakes Res 41: 45-58. https://doi.org/ 10.1016/j.jglr.2014.11.012.

Blumberg AF, Mellor GL. 1978. A coastal ocean numerical model, mathematical modeling of estuarine physics. In Sundermann J, Holz KP, eds. Proceedings of an International Symposium, Hamburg, August 24-26, Berlin: Springer-Verlag, pp 203-219.

Blumberg AF, Mellor GL. 1987. A description of a three-dimensional coastal ocean circulation model. In: Heaps N, ed. Three dimensional coastal ocean models, American Geophysics.

Born K, Fink AH, Knippertz P. 2010. Meteorological processes influencing the weather and climate of Morocco. In Speth P, Christoph M, Diekkrüger B, eds. Impacts of global change on the hydrological cycle in West and Northwest Africa, Berlin; Heidelberg: Springer, pp 150-163.

Brooks WR, Newbold SC. 2014. An updated biodiversity nonuse value function for use in climate change integrated assessment models. Ecol Econ 105: 342-349. https://doi.org/10.1016/j. ecolecon.2014.06.015.

Burchard H. 2002. Applied turbulence modeling in marine waters. Lecture notes in earth sciences. Berlin-Heidelberg-New YorkBarcelona-Hong Kong-London-Milan Paris-Tokyo: Springer, $215 \mathrm{p}$.

Chen C, Liu H, Beardsley RC. 2003. An unstructured grid, finitevolume, three-dimensional, primitive equations ocean model: application to coastal ocean and estuaries. J Atmos Ocean Technol 20: $159-186$.

Chen CS, Beardsley RC, Cowles G. 2006a. An unstructured grid, finite-volume coastal ocean model-FVCOM user manual. In Technical Report SMAST/UMASSD-06-0602 Second Edition. New Bedford: School for Marine Science and Technology, University of Massachusetts Dartmouth, 318 pp.
Chen CS, Beardsley RC, Cowles G. 2006b. An unstructured grid, finite-volume coastal ocean model (FVCOM) system. Oceanography 19: 78-89.

Chen C, Huang H, Beardsly RC, Liu H, Xu Q, Cowles G. 2007. A finite volume numerical approach for coastal ocean circulation studies: comparisons with finite difference models. J Geophys Res 112: C03018.

Conversa G, Bonasia A, Di Gioia F, Elia A. 2015. A decision support system (GesCoN) for managing fertigation in vegetable crops. Part II-model calibration and validation under different environmental growing conditions on field grown tomato. Front Plant Sci 6.

Coops H, Beklioglu M, Crisman TL. 2003. The role of water-level fluctuations in shallow lake ecosystems-workshop conclusions. Hydrobiologia 506: 23-27. https://doi.org/10.102/B: HYDR0000008595.14393.77.

De Waele J, Melis MT. 2009. Geomorphology and geomorphological heritage of the Ifrane-Azrou region (Middle Atlas, Morocco). Environ Geol 58: 587-599. DOI:10.1007/s00254-008-1533-4.

El-Nasr AA, Arnold JG, Feyen J, Berlamont J. 2005. Modelling the hydrology of a catchment using a distributed and a semi-distributed model. Hydrol Process 19: 573-587.

Fernandes LFS, dos Santos CMM, Pereira AP, Moura JP. 2011. Model of management and decision support systems in the distribution of water for consumption: case study in north Portugal. Eur J Environ Civ Eng 15: 411-426. https://doi.org/10.1080/ 19648189.2011.9693334.

Finlayson CM, Davis JA, Gell PA, Kingsford RT, Parton KA. 2013. The status of wetlands and the predicted effects of global climate change: the situation in Australia. Aquat Sci 75: 73-93. https://doi. org/10.1007/s00027-011-0232-5.

Guo H, Jiang T, Wang G, Su B, Wang Y. 2006. Observed trends and jumps of climate change over Lake Poyang Basin, China: 19612003. J Lake Sci 18: 443-451. https://doi.org/10.18307/2006.0501.

Gupta HV, Sorooshian S, Yapo PO. 1999. Status of automatic calibration for hydrologic models: comparison with multilevel expert calibration. J Hydrol Eng 4: 135-143.

Haddeland I, Heinke J, Biemans H, et al. 2014. Global water resources affected by human interventions and climate change. Proc Natl Acad Sci 111: 3251-3256. https://doi.org/10.1073/ pnas. 1222475110 .

Haddout S, Igouzal M, Maslouhi A. 2016. Analytical and numerical study of the salinity intrusion in the Sebou river estuary (Morocco)-effect of the Super Blood Moon (total lunar eclipse) of 2015. Hydrol Earth Syst Sci 20: 3923-3945.

Haddout S, Priya KL, Boko M, Azidane H. 2017a. Comparison of one-dimensional (1-D) column lake models prediction for surface water temperature in eight selected Moroccan lakes. ISH J Hydraul Eng 1-13.

Haddout S, Maslouhi A, Igouzal M. 2017b. Predicting of salt water intrusion in the Sebou river estuary (Morocco). J Appl Water Eng Res 5: 40-50.

Haghighi AT, Marttila H, Klove B. 2014. Development of a new index to assess river regime impacts after dam construction. Glob Planet Change 122: 186-196. https://doi.org/10.1016/j.glopla cha.2014.08.019.

Haghighi AT, Klove B. 2015. A sensitivity analysis of lake water level response to changes in climate and river regimes. Limnol Ecol Manag Inland Waters 51: 118-130. https://doi.org/10.1016/j. limno.2015.02.001.

Haghighi AT, Menberu MW, Aminnezhad M, Marttila H, Klove B. 2016. Can lake sensitivity to desiccation be predicted from lake geometry? J Hydrol 539: 599-610. https://doi.org/10.1016/j. jhydrol.2016.05.064. 
Hassan AA, Jin S. 2014. Lake level change and total water discharge in east africa rift valley from satellite-based observations. Glob Planet Change 117: 79-90. https://doi.org/10.1016/j.glopla cha.2014.03.005.

Huang HS, Chen CS, Cowles GW, et al. 2008. FVCOM validation experiments: comparisons with ROMS for three idealized barotropic test problems. J Phys Oceanogr 113: C07042. DOI:10.1029/2007JC004557.

Huang S, Dahal D, Young C, Chander G, Liu S. 2011. Integration of palmer drought severity index and remote sensing data to simulate wetland water surface from 1910 to 2009 in Cottonwood lake area, North Dakota. Remote Sens Environ 115: 3377-3389. https://doi. org/10.1016/j.rse.2011.08.002.

Hubbard ME. 1999. Multidimensional slope limiters for MUSCLtype finite volume schemes on unstructured grids. J Computat Phys 155: 54-74.

International Joint Commission. 2012. Lake superior regulation: addressing uncertainty in Upper Great Lakes water levels. Final Report, 28.

Jin S, Feng G. 2013. Large-scale variations of global groundwater from satellite gravimetry and hydrological models, 2002-2012. Glob Planet Change 106: 20-30. https://doi.org/10.1016/j.glopla cha.2013.02.008.

Kobayashi MH, Pereira JMC, Pereira JCF. 1999. A conservative finite-volume second order accurate projection method on hybrid unstructured grids. J Computat Phys 150: 40-75.

Knippertz P, Christoph M, Speth P. 2003. Long-term precipitation variability in Morocco and the link to the large-scale circulation in recent and future climates. Meteorol Atmos Phys 83: 67-88. DOI: 10.1007/s00703-002-0561-y.

Lai ZG, Chen CS, Cowles G, Beardsley RC. 2010a. A non-hydrostatic version of FVCOM, Part I: validation experiment. J Geophys Res 115. DOI:10.1029/2009JC005525.

Lai ZG, Chen CS, Cowles G, Beardsley RC. 2010b. A nonhydrostatic version of FVCOM, Part II: mechanistic study of tidally generated nonlinear internal waves in Massachusetts Bay. $J$ Geophys Res. DOI: 10.1029/2010JC006331.

Lamb H, Roberts N, Leng M, Barker P, Benkaddour A, van der Kaars S. 1999. Lake evolution in a semi-arid montane environment: response to catchment change and hydroclimatic variation. $J$ Paleolimnol 21: 325-343. DOI: 10.1023/A:1008099602205.

Mekonnen MM, Hoekstra AY, Becht R. 2012. Mitigating the water footprint of export cut flowers from the lake Naivasha Basin, Kenya. Water Res Manag 26: 3725-3742. https://doi.org/10.1007/ s11269-012-0099-9.

Mellor GL. 2003. The three-dimensional current and surface wave equations. J Phys Oceanogr 33: 1978-1989.

Mellor GL. 2005. Some consequences of the three- dimensional currents and surface wave equations. J Phys Oceanogr 35: 2291-2298.

Mellor GL. 2008. The depth-dependent current and wave interaction equations: a revision. J Phys Oceanogr 38: 2587-2596.

Mellor GL, Yamada T. 1982. Development of a turbulence closure model for geophysical fluid problem. Rev Geophys Space Phys 20: 851-875.

Mendoza ME, Bocco G, Bravo M, Granados EL, Osterkamp WR. 2006. Predicting water-surface fluctuation of continental lakes: a RS and GIS based approach in central Mexico. Water Res Manag 20: 291-311. https://doi.org/10.1007/s11269-006-8199-z.

Menjour F, Amraoui F, Remmal T. 2016. Assessment of the spatiotemporal evolution of Aguelmam Sidi Ali Lake using multi- temporal landsat imagery (Middle Atlas-Morocco). In 6th International Conference on Cartography and Gis p. 588.

Mistry VV, Conway D. 2003. Remote forcing of east African rainfall and relationships with fluctuations in levels of lake Victoria. Int $J$ Clim 23: 67-89. https://doi.org/10.1002/joc.861.

Moftakhari HR, Jay DA, Talke SA, Kukulka T, Bromirski PD. 2013. A novel approach to flow estimation in tidal rivers. Water Resour Res 49: 4817-4832. https://doi.org/10.1002/ wrcr.20363.

Moriasi DN, Arnold JG, Van Liew MW, Bingner RL, Harmel RD, Veith TL. 2007. Model evaluation guidelines for systematic quantification of accuracy in watershed simulations. Trans Asabe 50: 885-900.

Motiee H, McBean E. 2009. An assessment of long-term trends in hydrologic components and implications for water levels in lake superior. Hydrol Res 40: 564-579. https://doi.org/10.2166/ nh.2009.061.

Muvundja FA, Wüest A, Isumbisho M, et al. 2014. Modelling lake kivu water level variations over last seven decades. Limnol Ecol Manag Inland Water 47: 21-33. https://doi.org/10.1016/j. limno.2014.02.003.

Nash JE, Sutcliffe JV. 1970. River flow forecasting through conceptual models part I-A discussion of principles. J Hydrol 10: 282-290. DOI:10.1016/0022-1694(70)90255-6.

Njaya F, Snyder KA, Jamu D, et al. 2011. The natural history and fisheries ecology of lake Chilwa, Southern Malawi. J Gt Lakes Res 37: 15-25. https://doi.org/10.1016/j.jglr.2010.09.008.

Pengra B. 2012. The drying of Iran's Lake Urmia and its environmental consequences. UNEP-GRID, Sioux Falls, UNEP Global Environmental Alert Service (GEAS).

Rhanem M. 2009. L'alfa (Stipa tenacissima L.) dans la plaine de Midelt (haut bassin versant de la Moulouya, Maroc)-Éléments de climatologie. Physio-Géo 3: 1-20.

Ryner M, Gasse F, Rumes B, Verschuren D. 2007. Climatic and hydrological instability in semi-arid equatorial east Africa during the late glacial to holocene transition: a multi-proxy reconstruction of aquatic ecosystem response in northern tanzania. Palaeogeogr Palaeoclimatol Palaeoecol 248: 440-458. https://doi.org/10.1016/ j.palaeo.2006.12.014.

Santos RMB, Fernandes LS, Moura JP, Pereira MG, Pacheco FAL. 2014. The impact of climate change, human interference, scale and modeling uncertainties on the estimation of aquifer properties and river flow components. J Hydrol 519: 1297-1314. https://doi.org/ 10.1016/j.jhydrol.2014.09.001.

Sayad A, Chakiri S, Martin C, Bejjaji Z, Echarfaoui H. 2011. Effet des conditions climatiques sur le niveau du lac Sidi Ali (Moyen Atlas, Maroc). Physio-Géo Géogr Phys Environ 5: 251-268.

Stehr A, Debels P, Romero F, Alcayaga H. 2008. Hydrological modelling with SWAT under conditions of limited data availability: evaluation of results from a Chilean case study. Hydrol Sci J 53: 588-601.

Vaziri M. 1997. Predicting caspian sea surface water level by ANN and ARIMA models. J Waterway Port Coas Ocean Eng 123: 158162.

Woodbury LH, Padmanabhan G. 1989. Estimating terminal lake level frequencies, ASCE. J Water Resour Plan Manag 115: 321 337.

Yuan Y, Zeng G, Liang J, et al. 2015. Variation of water level in Dongting lake over a 50-year period: implications for impacts of anthropogenic and climatic factors. J Hydrol 525: 450-456. https:// doi.org/10.1016/j.jhydrol.2015.04.010. 
Zawiska I, Słowiński M, Correa-Metrio A, et al. 2015. The response of a shallow lake and its catchment to late glacial climate changes-a case study from eastern Poland. Catena 126: 1-10. https://doi.org/ 10.1016/j.catena.2014.10.007.

Zeinoddini M, Tofighi MA, Vafaee F. 2009. Evaluation of dike-type causeway impacts on the flow and salinity regimes in Urmia Lake. Iran J Gt Lake Res 35: 13-22.
Zhaoqing Y, Tarang Kh. 2008. Modeling of salt intrusion, intertidal mixing, and circulation in a Braided estuary. J Coas Res 52: $171-$ 180.

Zielhofer C, Fletcher WJ, Mischke S, et al. 2017. Atlantic forcing of Western Mediterranean winter rain minima during the last 12,000 years. Quat Sci Rev 157: 29-51.

Zilefac EA. 2010. Analysis of climate variability and anthropogenic impacts on the water balance of lake chad drainage basin.

Cite this article as: Haddout S, Jamali A, Rhazi M, Aghfir M. 2018. Finite volume coastal ocean model for water-level fluctuation due to climate change in Aguelmam Sidi Ali Lake (Middle Atlas, Morocco). Ann. Limnol. - Int. J. Lim. 54: 5 